\title{
Modification of the Modigliani-Miller Theory for the Case of Advance Payments of Tax on Profit
}

\author{
P.N. Brusov ${ }^{1, *}$, T.V. Filatova ${ }^{2}$, N.P. Orekhova ${ }^{3}$, V.L. Kulik ${ }^{4}$, S.-I. Chang ${ }^{5}$ and Y.C.G. Lin $^{5}$ \\ ${ }^{1}$ Department of Data Analysis, Decision Making, and Financial Technology, Financial University under the \\ Government of Russian Federation, Moscow, Russia \\ ${ }^{2}$ Department of Corporate Finance and Corporate Governance, Financial University under the Government of \\ Russian Federation. Moscow, Russia
}

${ }^{3}$ High Business School, Southern Federal University, Rostov-on-Don, Russia

${ }^{4}$ Ltd HSBC Bank, Moscow, Russia

${ }^{5}$ College of Management, National Chung Cheng University, Taiwan

\begin{abstract}
The first serious study (and first quantitative study) of influence of capital structure of the company on its indicators of activities was the work by Nobel Prize Winners Modigliani and Miller. Their theory has a lot of limitations. One of the most important and seriouse assumptions of the Modigliani - Miller theory is that all financial flows as well as all companies are perpetuity. This limitation was lift out by Brusov-Filatova-Orekhova in 2008 (Filatova et al. 2008), who have created BFO theory - modern theory of capital cost and capital structure for companies of arbitrary age.
\end{abstract}

Despite the fact that the Modigliani-Miller theory is currently a particular case of the general theory of capital cost and capital structure - Brusov-Filatova-Orekhova (BFO) theory - it is still widely used at the West.

In current paper we discuss one more limitation of Modigliani - Miller theory: a method of tax on profit payments. Modigliani - Miller theory accounts these payments as annuity-immediate while in practice these payments are making in advance and thus should be accounted as annuity-due.

\begin{abstract}
We generalize the Modigliani-Miller theory for the case of advance payments of tax on profit, which is widely used in practice, and show that this leads to some important consequencies, which change seriously all the main statements by Modigliani and Miller. These consequencies are as following: WACC starts to depend on debt cost $\mathrm{k}_{\mathrm{d}}$, WACC turns out to be lower than in case of classical Modigliani-Miller theory and thus company capitalization becomes higher than in ordinary Modigliani-Miller theory.We show that dependence of equity cost on leverage level $L$ is still linear, but the tilt angle with respect to $\mathrm{L}$-axis turns out to be smaller: this could lead to modification of the divident policy of the company.

Correct account of a method of tax on profit payments demonstrates that shortcomings of Modigliani - Miller theory are dipper, than everybody suggested: the underestimation of WACC really turns out to be bigger, as well as overestimation of the capitalization of the company. This means that systematic risks arising from the use of modified Modigliani - Miller theory (MMM theory) (which is more correct than "classical' one) in practice are higher than it was suggested by the "classical" version of this theory.
\end{abstract}

Keywords: Modigliani-Miller theory, advance payments of tax on profit, Brusov-Filatova-Orekhova theory, annuity-immediate, annuity-due.

\section{INTRODUCTION}

Under the capital structure, one understands the relationship between equity and debt capital of the company. Does capital structure affect the company's main settings, such as the cost of capital, profit, value of the company, and the others, and, if affects, how? Choice of an optimal capital structure, i.e., a capital structure, which minimizes the weighted average cost of capital, WACC, and maximizes the value of the company, $V$, is one of the most important tasks solved by financial manager and by the management of a

*Address correspondence to this author at the Department of Data Analysis, Decision Making, and Financial Technology, Financial University under the Government of Russian Federation, Moscow, Russia; Tel: +7-9060675975; Fax: +7-9060675975; E-mail: pnb1983@yahoo.com

JEL Classification: C53,L94,Q47. company. The first serious study (and first quantitative study) of influence of capital structure of the company on its indicators of activities was the work by Modigliani and Miller (1958). Until this study, the approach existed (let us call it traditional), which was based on empirical data analysis.

One of the most important assumptions of the Modigliani - Miller theory is that all financial flows are perpetuity. This limitation was lift out by BrusovFilatova-Orekhova in 2008 (Filatova et al. 2008), who have created BFO theory - modern theory of capital cost and capital structure for companies of arbitrary age (BFO-1 theory) and for companies of arbitrary life time (BFO-2 theory) (Brusov et al. 2015). In Figure 1 the historical development of capital structure theory from the traditional (empirical) approach, through 
perpetuity Modigliani-Miller approach to general capital structure theory - Brusov-Filatova-Orekhova (BFO) theory is shown.

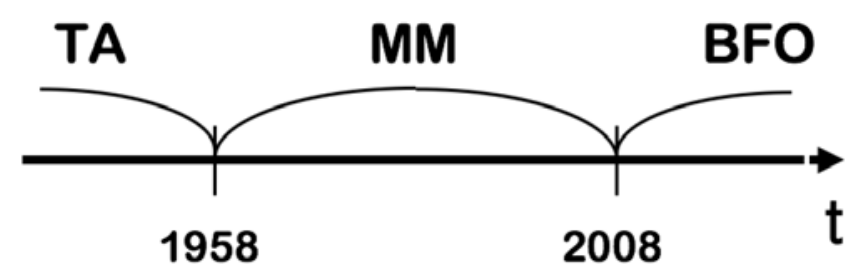

Figure 1: Historical development of capital structure theory (here TA - traditional (empirical) approach, MM - Modigliani - Miller approach, BFO - Brusov-Filatova-Orekhova theory).

In 2001 Steve Myers has considered the case of one-year company and show that in this case the weighted average cost of capital, WACC, is higher than in Modigliani-Miller case, and the capitalization of the company, $V$, is less than in Modigliani-Miller case.

So, before 2008 only two results for capital structure of the company were available: Modigliani-Miller for perpetuity company and Myers for one-year company (see Figure 2). BFO theory has filled out whole interval between $\mathrm{t}=1$ and $\mathrm{t}=\infty$. It gives the possibility to calculate the capitalization $V$, the weighted average cost of capital, WACC, equity cost $k_{e}$ and other financial parameters for companies of arbitrary age and for companies of arbitrary life-time. BFO theory has lead to a lot of new meaningful effects in modern capital structure theory, discussed in the monograph (Brusov et al., 2015; 2018).

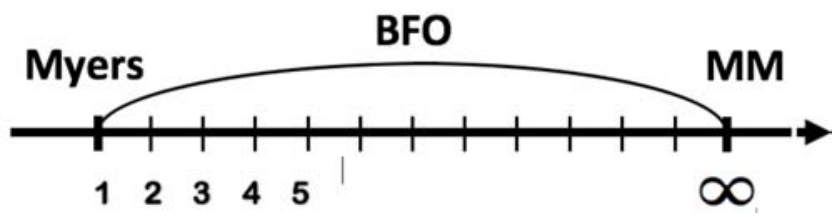

Figure 2: MM theory describes perpetuity limit, Myers paper describes one-year company while BFO theory fills the whole numeric axis (from $\mathrm{n}=1$ up to perpetuity limit $n=\infty$ ).

\section{THE TRADITIONAL APPROACH}

The traditional (empirical) approach told that weighted average cost of capital, WACC, and the associated company capitalization, $V=\mathrm{CF} / \mathrm{WACC}$, depend on the capital structure, the level of leverage, $L$. Debt cost always turns out to be lower than equity cost because first one has lower risk, via the fact, that in the event of bankruptcy creditor claims are met prior to shareholders claims.

As a result, an increase in the proportion of lowercost debt capital in the overall capital structure up to the limit which does not cause violation of financial sustainability and growth of risk of bankruptcy leads to lower weighted average cost of capital, WACC.

The profitability required by investors (the equity cost) is growing; however, its growth has not led to compensation of benefits from use of lower-cost debt capital. Therefore, the traditional approach welcomes the increased leverage $L=D / S$ and the associated increase of company capitalization. The traditional (empirical) approach has existed up to appearance of the first quantitative theory by Modigliani and Miller (1958).

\section{MODIGLIANI-MILLER THEORY}

\subsection{Modigliani-Miller Theory Without Taxes}

Modigliani and Miller (MM) in their first paper (Modigliani and Miller 1958) have come to the conclusions which were fundamentally different from the conclusions of traditional approach. Under assumptions (see Sect. 2.3 for details) that there are no taxes, no transaction costs, no bankruptcy costs, perfect financial markets exist with symmetry information, equivalence in borrowing costs for both companies and investors, etc., they have showed that choosing of the ratio between the debt and equity capital does not affect company value as well as capital costs (Figure 3).

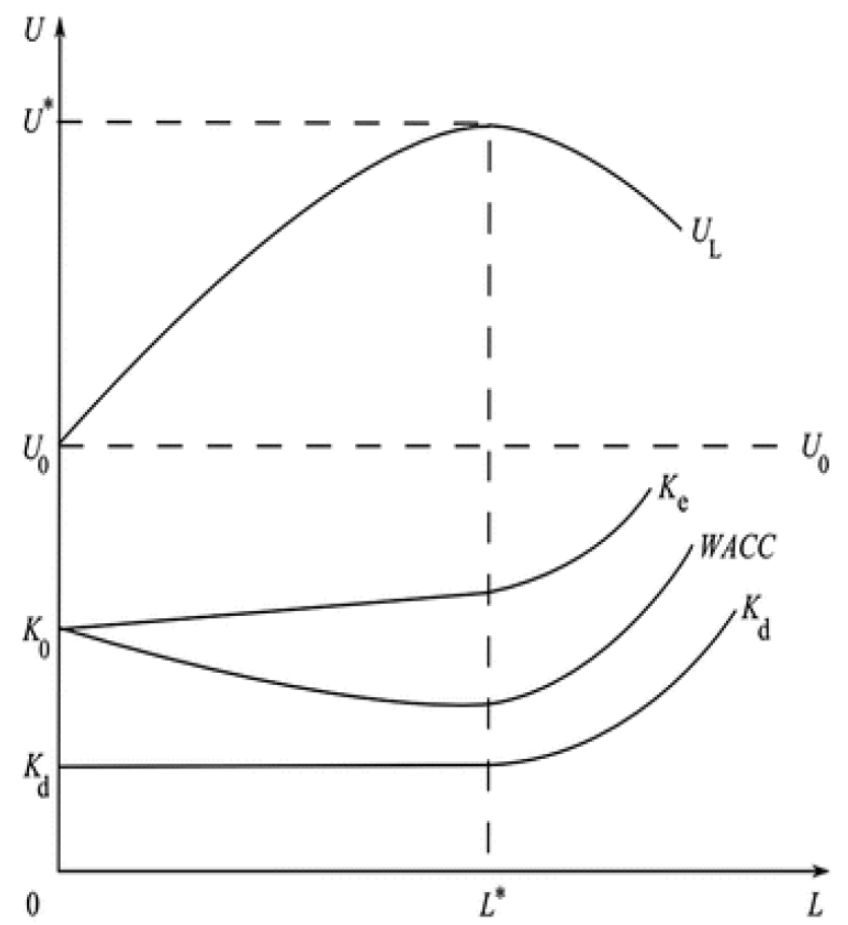

Figure 3: Dependence of company capitalization, $U_{\mathrm{L}}$, equity cost, $k_{\mathrm{e}}$, debt cost, $k_{\mathrm{d}}$, and weighted average cost of capital, WACC, in traditional (empirical) approach. 
Under above assumptions, Modigliani and Miller have analyzed the impact of financial leverage, supposing the absence of any taxes (on corporate profit as well as individual one). They have formulated and proven two following statements.

Without taxes, the total cost of any company is determined by the value of its EBIT-Earnings Before Interest and Taxes, discounted with fixed rate $\mathrm{k}_{0}$, corresponding to group of business risk of this company:

$V_{\mathrm{L}}=V_{\mathrm{U}}=\frac{\mathrm{EBIT}}{k_{0}}$.

Index $L$ means financially dependent company (using debt financing), while index $U$ means a financially independent company.

Authors supposed that both companies belong to the same group of business risk, and $k_{0}$ corresponds to required profitability of financially independent company, having the same business risk.

Because, as it follows from the formula (Eq. 1), value of the company does not depend on the value of debt, than according to Modigliani-Miller theorem (Modigliani and Miller 1958), in the absence of taxes, value of the company is independent of the method of its funding. This means as well that weighted average cost of capital, WACC, of this company does not depend on its capital structure and is equal to the capital cost, which this company will have under the funding by equity capital only.

$V_{0}=V_{\mathrm{L}} ; \mathrm{CF} / k_{0}=\mathrm{CF} / \mathrm{WACC}$, and thus $\mathrm{WACC}=k_{0}$.

Note that first Modigliani-Miller theorem is based on suggestion about independence of weighted average cost of capital and debt cost on leverage level.

From the first Modigliani-Miller theorem (Modigliani and Miller 1958), it is easy to derive an expression for the equity capital cost

$\mathrm{WACC}=k_{0}=k_{\mathrm{e}} w_{\mathrm{e}}+k_{\mathrm{d}} w_{\mathrm{d}}$.

Finding from here $k_{\mathrm{e}}$, one gets

$$
\begin{aligned}
& k_{\mathrm{e}}=\frac{k_{0}}{w_{\mathrm{e}}}-k_{\mathrm{d}} \frac{w_{\mathrm{d}}}{w_{\mathrm{e}}}=\frac{k_{0}(S+D)}{S}-k_{\mathrm{d}} \frac{D}{S} \\
& =k_{0}+\left(k_{0}-k_{\mathrm{d}}\right) \frac{D}{S}=k_{0}+\left(k_{0}-k_{\mathrm{d}}\right) L
\end{aligned}
$$

Here,

$$
\begin{aligned}
& \text { D value of debt capital of the company } \\
& \text { S value of equity capital of the company } \\
& k_{\mathrm{d}}, w_{\mathrm{d}}=\frac{D}{D+S} \\
& k_{\mathrm{e}}, w_{\mathrm{e}}=\frac{S}{D+S} \\
& L=D / S \\
& \text { WACC } \\
& \text { cost and fraction of debt capital of the company } \\
& \text { cost and fraction of equity capital of the } \\
& \text { company } \\
& \text { financial leverage } \\
& \text { weighted average cost of capital, }
\end{aligned}
$$

Thus, we come to second statement (theorem) of Modigliani-Miller theory about the equity cost of financially dependent (leverage) company (Modigliani and Miller 1958).

Equity cost of leverage company $k_{\mathrm{e}}$ could be found as equity cost of financially independent company $k_{0}$ of the same group of risk, plus premium for risk, the value which is equal to production of difference $\left(k_{0}-k_{\mathrm{d}}\right)$ on leverage level $L$ :

$k_{\mathrm{e}}=k_{0}+\left(k_{0}-k_{\mathrm{d}}\right) L$

Formula (Eq. 4) shows that equity cost of the company increases linearly with leverage level (Figure 3).

The combination of these two Modigliani-Miller statements implies that the increasing of level of debt in the capital structure of the company does not lead to increased value of firms, because the benefits gained from the use of more low-cost debt capital markets will be exactly offset by an increase in risk (we are speaking about the financial risk, the risk of bankruptcy) and, therefore, by an increase in cost of equity capital of firms: investors will increase the required level of profitability under increased risk, by which a higher level of debt in the capital structure is accompanied.

In this way, the Modigliani-Miller theorem argues that in the absence of the taxes, the capital structure of the company does not affect the value of the company and its weighted average cost of capital, WACC, and equity cost increases linearly with the increase of financial leverage.

Explanations, given by Modigliani and Miller under receiving of their conclusions, are the following (Modigliani and Miller, 1958). Value of the company depends on profitability and risk only and does not depend on the capital structure. Based on the principle 
of preservation of the value, they postulated that the value of the company, which is equal to the sum of the equity and debt funds, is not changed when the ratio between its parts is changed. An important role in justification of Modigliani-Miller statements an existence of an arbitral awards opportunities for the committed markets plays. Two identical companies, differing only by the leverage level, must have the same value. If this is not the case, the arbitration aligns business cost: investors of less cost company can invest capital in a company of more value. Selling of shares of the first company and buying of stock of the second company will continue until the values of both companies are not equalized.

Most of Modigliani and Miller assumptions (Modigliani and Miller 1958), of course, are unrealistic. Some assumptions can be removed without changing the conclusions of the model. However, assuming no costs of bankruptcy and the absence of taxes (or the presence of corporate taxes only) are crucial-the change of these assumptions alters conclusions. The last two assumptions rule out the possibility of signaling theory and agency costs theory and, thus, also constitute a critical prerequisite (Figure 4).

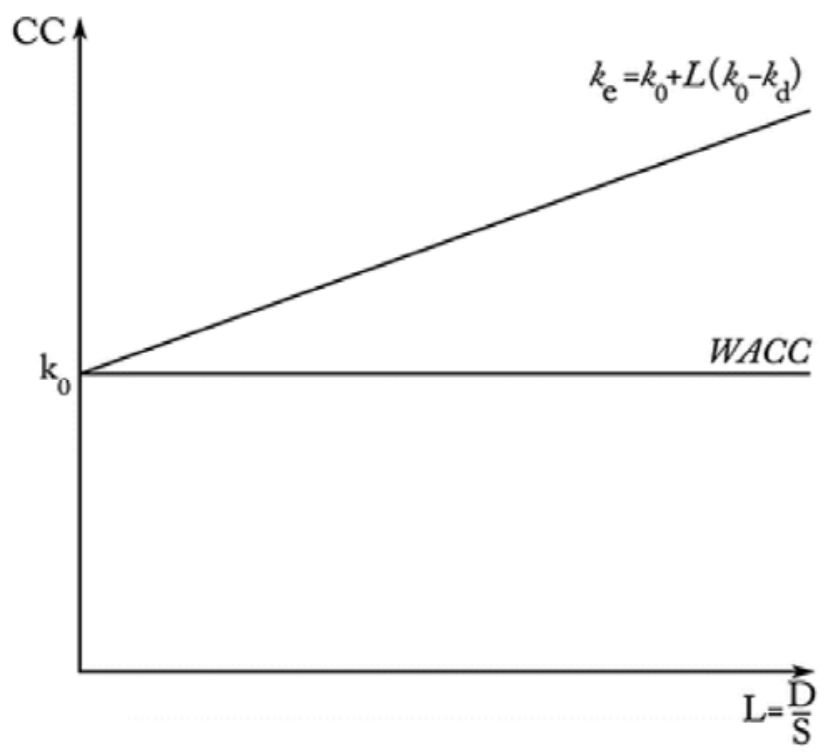

Figure 4: Dependence of equity cost $k_{\mathrm{e}}$ and WACC on leverage level $L$ within Modigliani-Miller theory without taxes.

\subsection{Modigliani-Miller Theory with Taxes}

In the real situation, taxes on profit of companies always exist. Since the interest paid on debt are excluded from the tax base-it leads to the so-called effect of "tax shield": value of the company that used the borrowed capital (leverage company) is higher than the value of the company that financed entirely by the equity (non-leverage company). The value of the "tax shield" for 1 year is equal to $k_{\mathrm{d}} D T$, where $D$-the value of debt, $T$-the income tax rate, and $k_{\mathrm{d}}$-the interest on the debt (or debt capital cost) (Modigliani and Miller 1963). The value of the "tax shield" for perpetuity company for all time of its existence is equal to (we used the formula for the sum of terms of an infinitely decreasing geometric progression)

$$
(\mathrm{PV})_{\mathrm{TS}}=k_{\mathrm{d}} D T \sum_{t=1}^{\infty}\left(1+k_{\mathrm{d}}\right)^{-t}=D T
$$

and the cost of leverage company is equal to

$$
V=V_{0}+D T
$$

where $V_{0}$ is the value of financially independent company.

Thus, we obtain the following result obtained by Modigliani and Miller (1963):

The value of financially dependent company is equal to the value of the company of the same risk group used no leverage, increased by the value of tax shield arising from financial leverage, and equal to the product of rate of corporate income tax $T$ and the value of debt $D$.

Let us now get the expression for the equity capital cost of the company under the existence of corporate taxes.

Accounting that $V_{0}=\mathrm{CF} / k_{0}$ and that the ratio of debt capital $w_{\mathrm{d}}=D / V$, one gets

$V=\mathrm{CF} / k_{0}+w_{\mathrm{d}} V T$.

Because the value of leverage company is $V=\mathrm{CF} / \mathrm{WACC}$, for weighted average cost of capital, WACC, we get

$$
\mathrm{WACC}=k_{0}\left(1-w_{\mathrm{d}} T\right) .
$$

From here the dependence of WACC on leverage $L=D / S$ becomes the following:

$$
\mathrm{WACC}=k_{0}(1-L T /(1+L)) .
$$

On the other hand, on definition of the weighted average cost of capital with "tax shield" accounting, we have 
$\mathrm{WACC}=k_{0} w_{\mathrm{e}}+k_{\mathrm{d}} w_{\mathrm{d}}(1-T)$.

Equating Eqs. (9) and (11), one gets

$k_{0}\left(1-w_{\mathrm{d}} T\right)=k_{0} w_{\mathrm{e}}+k_{\mathrm{d}} w_{\mathrm{d}}(1-T)$

and from here, for equity cost, we get the following expression:

$$
\begin{aligned}
k_{\mathrm{e}} & =k_{0} \frac{\left(1-w_{\mathrm{d}} T\right)}{w_{\mathrm{e}}}-k_{\mathrm{d}} \frac{w_{\mathrm{d}}}{w_{\mathrm{e}}}(1-T)=k_{0} \frac{1}{w_{\mathrm{e}}}-k_{0} \frac{w_{\mathrm{d}}}{w_{\mathrm{e}}} T-k_{\mathrm{d}} \frac{D}{S}(1-T) \\
& =k_{0} \frac{D+S}{S}-k_{0} \frac{D}{S} T-k_{\mathrm{d}} \frac{D}{S}(1-T)=k_{0}+L(1-T)\left(k_{0}-k_{\mathrm{d}}\right) .
\end{aligned}
$$

So, we get the following statement obtained by Modigliani and Miller (1963):

Equity cost of leverage company $k_{\mathrm{e}}$ paying tax on profit could be found as equity cost of financially independent company $k_{0}$ of the same group of risk, plus premium for risk, the value which is equal to production of difference $\left(k_{0}-k_{\mathrm{d}}\right)$ on leverage level $L$ and on tax shield $(1-t)$.

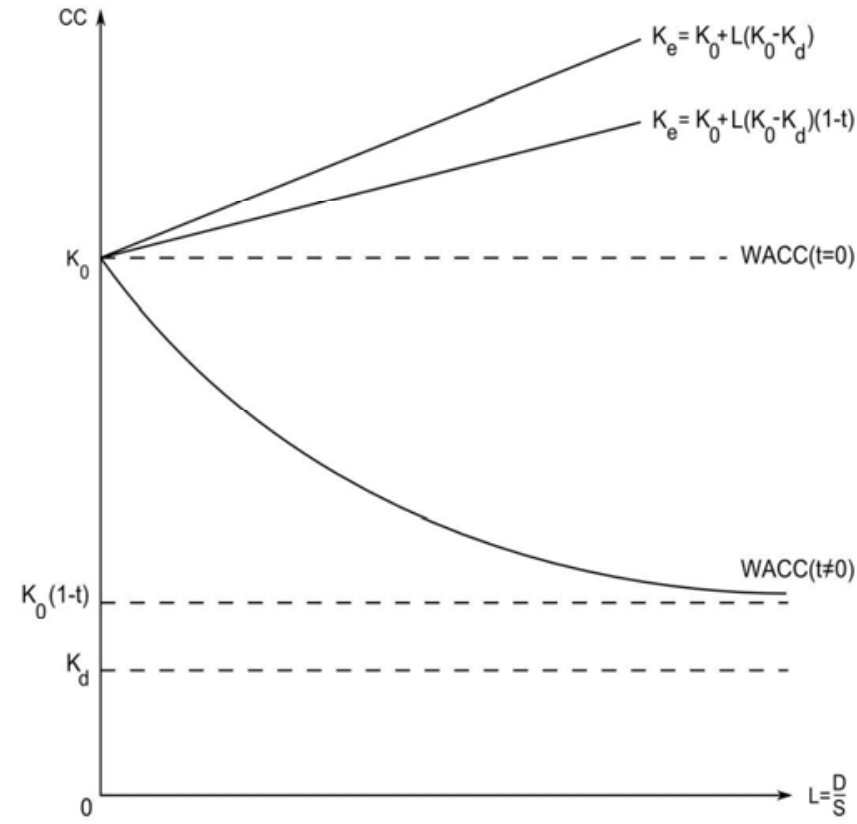

Figure 5: Dependence of equity capital cost, debt cost, and WACC on leverage in Modigliani-Miller theory without taxes $(t=0)$ and with taxes $(t \neq 0)$.

It should be noted that the formula (Eq. 12) is different from the formula (Eq. 4) without tax only by the multiplier $(1-t)$ in term, indicating a premium for risk. As the multiplier is less than unit, the corporate tax on profits leads to the fact that capital is growing with the increasing of financial leverage, slower than it would have been without them.
By the analysis of formulas (Eqs. (4), (9), and (12)) Modigliani and M iller (1963) had come to following conclusions. When leverage grows:

1. Value of company increases.

2. Weighted average cost of capital WACC decreases from $k_{0}$ (at $L=0$ ) up to $k_{0}(1-T)$ (at $L=\infty$ ) (when the company is funded solely by borrowed funds).

3. Equity cost increases linearly from $k_{0}$ (at $L=0$ ) up to $\infty($ at $L=\infty)$.

\subsection{Main Assumptions of Modigliani-Miller Theory}

The most important assumptions of the ModiglianiMiller theory are as following:

1. Investors are behaving rationally and instantaneously, see profit opportunity, inadequate investment risk. Therefore, the possibility of a stable situation of the arbitration, i.e., obtain the risk-free profit on the difference in prices for the same asset cannot be kept any length of time-reasonable investors quickly take advantage of it for their own purposes and equalize conditions in the market. This means that in a developed financial market capital, the same risk should be rewarded by the same rate of return.

2. Investment and financial market opportunities should be equally accessible to all categories of investors-whether institutional or individual investors, large or small, rapidly growing or stable, or experienced or relatively inexperienced.

3. Transaction costs associated with funding are very small. In practice, the magnitude of transaction costs is inversely proportional to the amount of finance involved, so this assumption is more consistent with reality than the large sums involved: i.e., in attracting small amounts, the transaction costs can be high, while, as in attracting large loans, as well as during placement of shares at a significant amount, the transaction costs can be ignored.

4. Investors get money and provide funds to borrowers at risk-free rate. In all probability, this assumption is due to the fact that the lender seeks to protect himself by using one or other 
guarantees, pledge of assets, the right to pay claims on third parties, and the treaty provisions restricting the freedom of the borrower to act to the detriment of the creditor. Lender's risk is really small, but its position can be considered risk free with respect to the position of the borrower and, accordingly, should be rewarded by a risk-free rate of return.

5. Companies have only two types of assets: riskfree debt capital and risky equity capital.

6. There is no possibility of bankruptcy, i.e., irrespective of what the level of financial leverage of the company-borrowers are reached-bankruptcy is not threatening them. Thus, bankruptcy costs are absent.

7. There are no corporate taxes and taxes on personal income of investors. If the personal income tax can indeed be neglected, because the assets of the company separated from the assets of shareholders, the corporate income taxes should be considered in the development of more realistic theories (which was done by Modigliani and Miller in their second paper devoted to the capital structure (Modigliani et al., 1963).

8. Companies are in the same class of risky companies.

9. All financial flows are perpetuity.

10. Companies have the same information.

11. Management of the company maximizes the capitalization of the company.

3. MODIFIED MODIGLIANI-MILLER THEORY IN CASE OF ADVANCE PAYMENTS OF TAX ON PROFIT

\subsection{Tax Shield}

To calculate tax shield TS in case of advance tax payments one should use annuity-due (Figure 6).

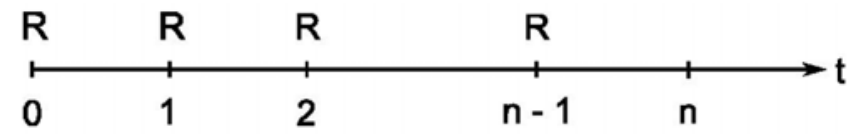

Figure 6: Annuity-due.

$T S=k_{d} D t+\frac{k_{d} D t}{\left(1+k_{d}\right)}+\frac{k_{d} D t}{\left(1+k_{d}\right)^{2}}+\ldots=\frac{k_{d} D t}{\left(1-\left(1+k_{d}\right)^{-1}\right)}=D t\left(1+k_{d}\right)$
This expression is different from the case of classical Modigliani-Miller theory (which used annuityimmediate) (Figure 7).

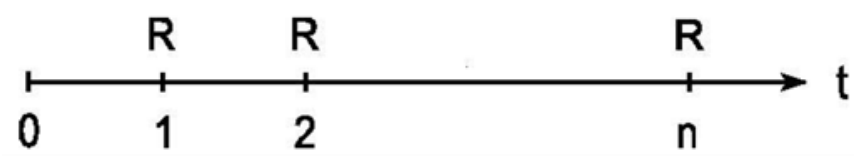

Figure 7: Annuity-immediate.

$$
T S=\frac{k_{d} D t}{\left(1+k_{d}\right)}+\frac{k_{d} D t}{\left(1+k_{d}\right)^{2}}+\ldots=\frac{k_{d} D t}{\left(1+k_{d}\right)\left(1-\left(1+k_{d}\right)^{-1}\right)}=D t
$$

Thus in the former case tax shield TS is bigger by multiplyer $\left(1+k_{d}\right)$. This is connected with the time value of money: money today is more expensive than money tomorrow due to the possibility of their alternative investment.

\subsection{Capitalization of the Company}

Modigliani-Miller theorem for capitalization of the company

$V=V_{0}+T S$

takes the following form

$V=V_{0}+D t\left(1+k_{d}\right)$.

Thus, we arrive to the following statement, which modifies the original Modigliani and Miller.

The value of financially dependent company making payments in advance of tax on profit is equal to the value of the company of the same risk group used no leverage, increased by the value of tax shield arising from financial leverage, and equal to the product of rate of corporate income tax $t$, the value of debt $D$ and multiplyer $\left(1+k_{d}\right)$.

\section{Substituting $D=w_{d} \cdot V$}

one has

$V\left(1-w_{d} t\left(1+k_{d}\right)\right)=V_{0}$

$\frac{C F}{W A C C} \cdot\left(1-w_{d} t\left(1+k_{d}\right)\right)=\frac{C F}{k_{0}}$

And for WACC we have the following formula:

$W A C C=k_{0}\left(1-w_{d} t\left(1+k_{d}\right)\right)$.

At $L \rightarrow \infty$ WACC $=k_{0}\left(1-t\left(1+k_{d}\right)\right)$. 
This expression is different from the similar one in classical Modigliani-Miller theory

$W A C C=k_{0}\left(1-w_{d} t\right)$

At $L \rightarrow \infty \quad W A C C=k_{0}(1-t)$.

From these expressions it is seen that WACC decreases with $\mathrm{L}$, achieving lower value $W A C C=k_{0}\left(1-t\left(1+k_{d}\right)\right)$ at $L \rightarrow \infty$ in considering case comparing with classical Modigliani-Miller theory $W A C C=k_{0}(1-t)$.

This means also, that company capitalization becomes higher than in ordinary Modigliani-Miller theory.

\subsection{Equity Cost}

Let us find equity cost

$W A C C=k_{e} w_{e}+k_{d} w_{d}(1-t)$.

Equating (9) and (11), we obtain

$k_{0}\left(1-w_{d} t\left(1+k_{d}\right)\right)=k_{e} w_{e}+k_{d} w_{d}(1-t)$,

whence we get the following expression for the equity cost:

$k_{e}=k_{0} \frac{\left(1-w_{d} t\left(1+k_{d}\right)\right)}{w_{e}}-k_{d} \frac{w_{d}}{w_{e}}(1-t)=$

$=k_{0} \frac{1}{w_{e}}-k_{0} \frac{w_{d}}{w_{e}}\left(1+k_{d}\right) \cdot t-k_{d} \frac{D}{S}(1-t)=$

$=k_{0} \frac{D+S}{S}-k_{0} \frac{D}{S}\left(1+k_{d}\right) \cdot t-k_{d} \frac{D}{S}(1-t)=$

$=k_{0}+L\left[(1-t)\left(k_{0}-k_{d}\right)-k_{0} k_{d} t\right]$.
Finally, we have for the equity cost

$k_{e}=k_{0}+L\left[(1-t)\left(k_{0}-k_{d}\right)-k_{0} k_{d} t\right]$.

Thus, we arrive to the following statement, which modifies the original Modigliani and Miller.

Equity cost of leverage company $k_{\mathrm{e}}$ making tax on profit payments in advance could be found as equity cost of financially independent company $k_{0}$ of the same group of risk, plus premium for risk, the value which is equal to production of leverage level $L$ on production of difference $\left(k_{0}-k_{\mathrm{d}}\right)$ and tax shield $(1-t)$, decreasing by the value $k_{0} k_{d} t$.

This means, that equity cost dependence on leverage level $L$ is still linear, but the tilt angle with respect to $\mathrm{L}$-axis turns out to be smaller $\operatorname{tg} \alpha=\left(k_{0}-k_{d}\right) \cdot(1-t)-k_{0} k_{d} t$.

This could lead to modification of the dividend policy of the company, because the equity cost represents itself economically sound value of dividends. Thus, company could decrease the value of dividends, which it should pay to shareholders.

\section{COMPARISION OF THE RESULTS FOR WACC OF "CLASSICAL" MODIGLIANI-MILLER THEORY AND OF MODIFIED MODIGLIANI-MILLER THEORY (MMM THEORY)}

Let us calculate in Excel the dependence of WACC on leverage level in "classical" Modigliani-Miller theory and in modified Modigliani-Miller theory (MMM theory) for different values of debt costs $\mathrm{kd}$.

While in " classical" case WACC does NOT depend on debt costs kd (see formula (9)), in modified

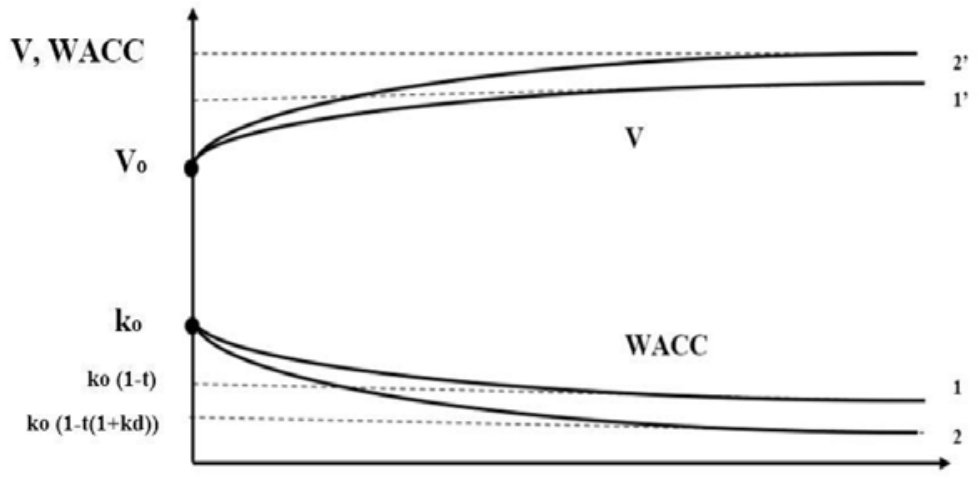

$\mathbf{L}$

Figure 8: Dependence of company capitalization, V and WACC on leverage level in "classical" Modigliani-Miller theory (curve 1 ' and curve 1) and in "modified" Modigliani-Miller theory (curve 2' and curve 2). 


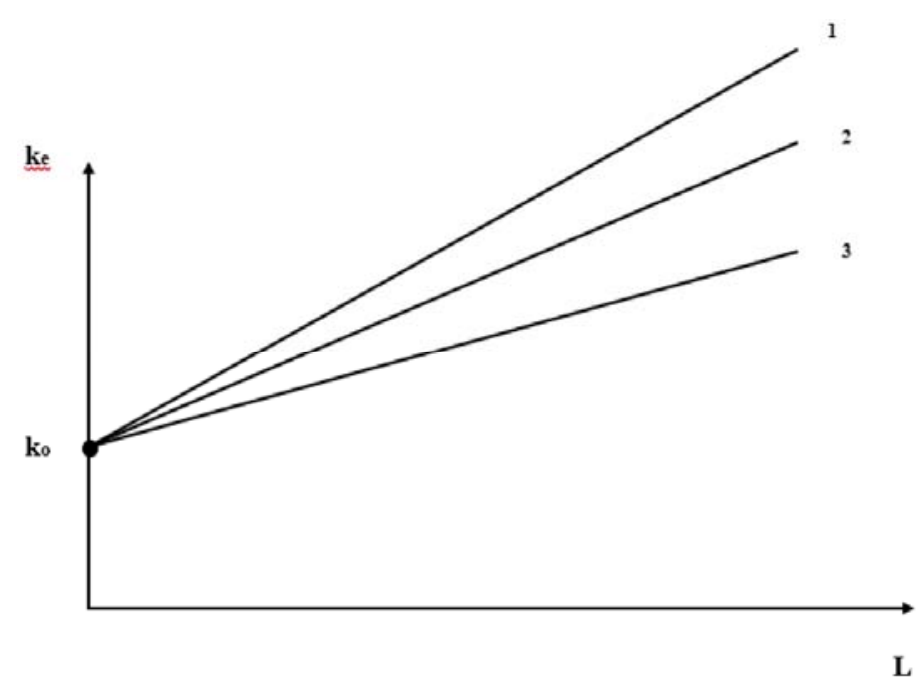

Figure 9: Dependence of equity cost of the company, ke, on leverage level in "classical" Modigliani-Miller theory (curve 2), in "modified" Modigliani-Miller theory (curve 3) and for financially independent company ( $\mathrm{t}=0$ ) (curve 1).

Table 1: Dependence of WACC on Leverage Level in "Classical" Modigliani-Miller Theory

\begin{tabular}{|c|c|c|c|}
\hline ko & $\mathbf{L}$ & $\mathbf{t}$ & WACC \\
\hline \hline 0.2 & 0 & 0.2 & 0.2000 \\
\hline 0.2 & 1 & 0.2 & 0.1800 \\
\hline 0.2 & 2 & 0.2 & 0.1733 \\
\hline 0.2 & 3 & 0.2 & 0.1700 \\
\hline 0.2 & 4 & 0.2 & 0.1680 \\
\hline 0.2 & 5 & 0.2 & 0.1667 \\
\hline 0.2 & 6 & 0.2 & 0.1657 \\
\hline 0.2 & 7 & 0.2 & 0.1650 \\
\hline 0.2 & 8 & 0.2 & 0.1644 \\
\hline 0.2 & 9 & 0.2 & 0.1640 \\
\hline 0.2 & 10 & 0.2 & 0.1636 \\
\hline
\end{tabular}

Table 2: Dependence of WACC on Leverage Level in Modified Modigliani-Miller Theory (MMM Theory) at kd=0.18

\begin{tabular}{|c|c|c|c|c|}
\hline ko & $\mathbf{L}$ & $\mathbf{t}$ & kd & WACC \\
\hline \hline 0.2 & 0 & 0.2 & 0.18 & 0.2000 \\
\hline 0.2 & 1 & 0.2 & 0.18 & 0.1685 \\
\hline 0.2 & 2 & 0.2 & 0.18 & 0.1646 \\
\hline 0.2 & 3 & 0.2 & 0.18 & 0.1622 \\
\hline 0.2 & 4 & 0.2 & 0.18 & 0.1607 \\
\hline 0.2 & 5 & 0.2 & 0.18 & 0.1595 \\
\hline 0.2 & 6 & 0.2 & 0.18 & 0.1587 \\
\hline 0.2 & 7 & 0.2 & 0.18 & 0.1580 \\
\hline 0.2 & 8 & 0.2 & 0.18 & 0.1575 \\
\hline 0.2 & 9 & 0.2 & 0.18 & 0.1571 \\
\hline
\end{tabular}


Table 3: Dependence of WACC on Leverage Level in Modified Modigliani-Miller Theory (MMM Theory) at kd=0.14

\begin{tabular}{|c|c|c|c|c|}
\hline ko & $\mathbf{L}$ & $\mathbf{t}$ & kd & 0.14 \\
\hline \hline 0.2 & 0 & 0.2 & 0.14 & 0.2000 \\
\hline 0.2 & 1 & 0.2 & 0.14 & 0.1772 \\
\hline 0.2 & 2 & 0.2 & 0.14 & 0.1696 \\
\hline 0.2 & 3 & 0.2 & 0.14 & 0.1658 \\
\hline 0.2 & 4 & 0.2 & 0.14 & 0.1620 \\
\hline 0.2 & 5 & 0.2 & 0.14 & 0.1609 \\
\hline 0.2 & 6 & 0.2 & 0.14 & 0.1601 \\
\hline 0.2 & 7 & 0.2 & 0.14 & 0.1595 \\
\hline 0.2 & 8 & 0.2 & 0.14 & 0.1590 \\
\hline 0.2 & 9 & 0.2 & 0.14 & 0.1585 \\
\hline
\end{tabular}

Table 4: Dependence of WACC on Leverage Level in modified Modigliani-Miller Theory (MMM Theory) at kd=0.1

\begin{tabular}{|c|c|c|c|c|}
\hline ko & $\mathbf{L}$ & $\mathbf{t}$ & kd & WACC \\
\hline \hline 0.2 & 0 & 0.2 & 0.1 & 0.2000 \\
\hline 0.2 & 1 & 0.2 & 0.1 & 0.1780 \\
\hline 0.2 & 2 & 0.2 & 0.1 & 0.1707 \\
\hline 0.2 & 3 & 0.2 & 0.1 & 0.1648 \\
\hline 0.2 & 4 & 0.2 & 0.1 & 0.1633 \\
\hline 0.2 & 5 & 0.2 & 0.1 & 0.1623 \\
\hline 0.2 & 6 & 0.2 & 0.1 & 0.1615 \\
\hline 0.2 & 7 & 0.2 & 0.1 & 0.1609 \\
\hline 0.2 & 8 & 0.2 & 0.1 & 0.1604 \\
\hline 0.2 & 10 & 0.2 & 0.1 & 0.1600 \\
\hline
\end{tabular}

Modigliani-Miller theory (MMM theory) WACC depends on debt costs kd (see formula (17)).

We will use in both cases equity cost $\mathbf{k}_{0}=0.2$ (at $L=0$ ), and in latter case debt cost $\mathbf{k d = 0 . 1 8 ; ~} \mathbf{k d = 0 . 1 4}$; $k d=0.1$.

From the Tables 1-4 and from Figure 10 that WACC in MMM theory turns out to be lower than in case of classical Modigliani-Miller theory and thus company capitalization becomes higher than in ordinary Modigliani-Miller theory. It is seen, that WACC decreases with debt cost $k_{d}$.

\section{CONCLUSIONS}

Despite the fact that the Modigliani-Miller theory is currently a particular case of the general theory of capital cost and capital structure - Brusov-FilatovaOrekhova (BFO) theory - it is still widely used at the West. We generalize the Modigliani-Miller theory for the case of advance payments of tax on profit, which is widely used in practice, and show that this leads to some important consequencies, which change seriously all the main statements by Modigliani and Miller. These consequencies are as following: WACC 


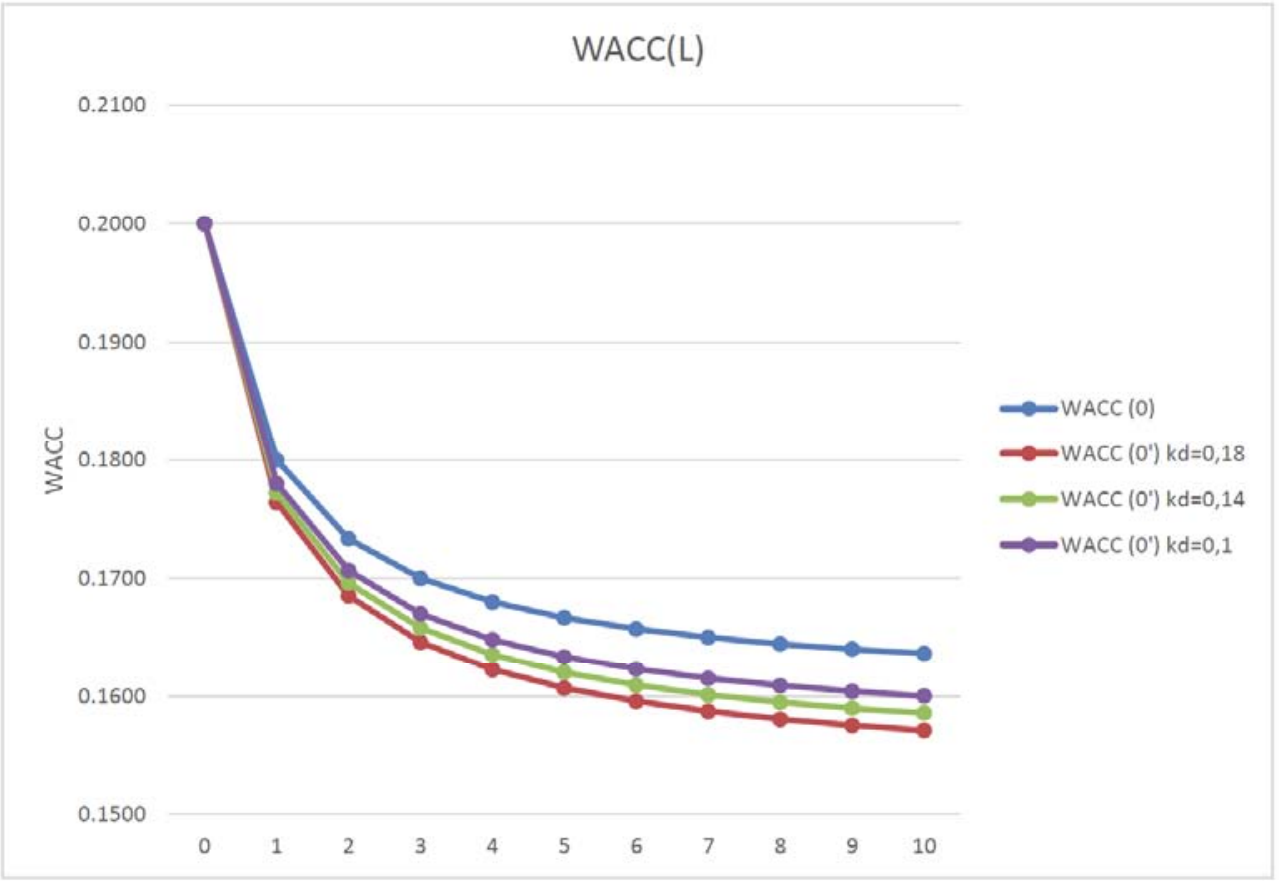

Figure 10: Dependence of WACC on leverage level L:

- in "classical" Modigliani-Miller theory (curve WACC(0)) and

- in modified Modigliani-Miller theory (MMM theory) at different values of debt cost: $k d=0.18 ; k d=0.14 ; k d=0.1$ (curves $\left.\operatorname{WACC}\left(0^{\prime}\right)\right)$.

starts to depend on debt cost $k_{d}$, WACC turns out to be lower than in case of classical Modigliani-Miller theory and thus company capitalization becomes higher than in ordinary Modigliani-Miller theory.We show that equity cost dependence on leverage level $L$ is still linear, but the tilt angle with respect to $L$-axis turns out to be smaller: this could lead to modification of the divident policy of the company. Because the equity cost represents itself economically sound value of dividends, thus company could decreases the value of dividends, which they should pay to shareholders.

Correct account of a method of payments of tax on profit demonstrates that shortcomings of Modigliani Miller theory are dipper, than everybody suggested: the underestimation of WACC really turns out to be bigger, as well as overestimation of the capitalization of the company. This means that systematic risks arising from the use of modified Modigliani - Miller theory (MMM theory) (which is more correct than "classical' one) in practice is higher than it was suggested by the "classical' version of this theory.

\section{REFERENCES}

Brusov P, Filatova T, Orehova N, Eskindarov M (2015), Modern corporate finance, investments and taxation, Springer International Publishing, Switzerland, 373 p. monograph, SCOPUS.https://www.springer.com/gp/book/9783319147314
Brusov P, Filatova T, Orehova N, Eskindarov M (2018), Modern corporate finance, investments, taxation and ratings, Springer Nature Publishing, Switzerland, 571 p. monograph

P.N. Brusov, T.V. Filatova, N.P. Orekhova, V.L. Kulik and I.Weil (2019) Ratings of the investment projects of arbitrary durations: New methodology Journal of Reviews on Global Economics, v.8, p. 437-448. SCOPUS, https://doi.org/10.6000/1929-7092.2019.08.37

Brusov P (2018) Editorial: Introduction on special issue on the Banking System and financial markets of Russia and other countries: Problems and prospects. Journal of Reviews on Global Economics , v.7, p. i-vi, SCOPUS

T.V. Filatova, P.N. Brusov, N.P. Orekhova and V.L. Kulik (2018) Ratings of the long-term projects: New approach Journal of Reviews on Global Economics , v.7, P. 645-661, SCOPUS https://doi.org/10.6000/1929-7092.2018.07.59

P.N. Brusov, T.V. Filatova, N.P. Orekhova and V.L. Kulik (2018) Rating: New approach Journal of Reviews on Global Economics, v.7, Pages 37-62 SCOPUS https://doi.org/10.6000/1929-7092.2018.07.05

P.N. Brusov, T.V. Filatova, N.P. Orekhova and V.L. Kulik (2018) A "golden age" of the companies: Conditions of its existence Journal of Reviews on Global Economics , v.7, p. 88-103. SCOPUS https://doi.org/10.6000/1929-7092.2018.07.07

P.N. Brusov, T.V. Filatova, N.P. Orekhova and V.L. Kulik (2018) Rating methodology: New look and new horizons Journal of Reviews on Global Economics, v.7, p. 63-87. SCOPUS https://doi.org/10.6000/1929-7092.2018.07.06

P.N. Brusov, T.V. Filatova, N.P. Orekhova, V.L. Kulik and I.Weil (2018) New meaningful effects in modern capital structure theory Journal of Reviews on Global Economics, v.7, p. 104122. SCOPUS https://doi.org/10.6000/1929-7092.2018.07.08

Brusov P (2018) Editorial, Journal of Reviews on Global Economics v.7, p. i-v, SCOPUS 
Peter Brusov, Tatiana Filatova, Natali Orekhova, Veniamin Kulik, Irwin Weil and Andrey Brailov (2018) The impact of the central bank key rate and commercial banks credit rates on creating and maintaining of a favorable investment climate in the country Journal of Reviews on Global Economics, v.7, p.360-376 SCOPUS https://doi.org/10.6000/1929-7092.2018.07.31

Brusov PN, Filatova TV, Orekhova NP, (2018) Modern corporate finance and investments, monograph, Knorus publishing house, Moscow, $517 \mathrm{p}$.

Filatova T, Orehova N, Brusova A (2008) Weighted average cost of capital in the theory of Modigliani-Miller, modified for a finite life-time company. Bull FU 48:68-77
T.V. Filatova, P.N. Brusov, N.P. Orekhova and V.L. Kulik (2018) Ratings of the long-term projects: New approach Journal of Reviews on Global Economics , v.7, P. 645-661, SCOPUS https://doi.org/10.6000/1929-7092.2018.07.59

Modigliani F, Miller M (1958) The cost of capital, corporate finance, and the theory of investment. Am Econ Rev 48:261-297

Modigliani F, Miller M (1963) Corporate income taxes and the cost of capital: a correction. Am Econ Rev 53:147-175

Modigliani F, Miller M (1966) Some estimates of the cost of capital to the electric utility industry 1954-1957. Am Econ Rev 56:333391

Myers S (2001) Capital structure. J Econ Perspect 15(2):81-102.

Received on 12-04-2020

Accepted on 09-05-2020

Published on 18-06-2020

DOI: https://doi.org/10.6000/1929-7092.2020.09.25

(C) 2020 Brusov et al.; Licensee Lifescience Global.

This is an open access article licensed under the terms of the Creative Commons Attribution Non-Commercial License (http://creativecommons.org/licenses/by-nc/3.0/) which permits unrestricted, non-commercial use, distribution and reproduction in any medium, provided the work is properly cited. 